\title{
TYPOLOGISCHE BENADERING VAN ENKELE MUNTGEWICHTENDOZEN UIT DE VERZAMELING VAN HET BIJLOKEMUSEUM GENT
}

door

\section{Y. HOLLEBOSCH - VAN RECK}

\section{INLEIDING}

Het Bijlokemuseum te Gent bezit een vrij interessante en rijke verzameling muntgewichtendozen, die tot voor kort voor het publiek verborgen bleef en waarover slechts zeer summier gerept werd in de algemene catalogus van 1886 van het Oudheidkundig Museum door de toenmalige conservator $\mathrm{H}$. Van Duyse.

Verscheidene van deze voorwerpen zijn afkomstig uit de vroegere verzameling van L. Minard van Gent, die geveild werd in 1883. Sindsdien werd geen gewag meer gemaakt over deze collectie, tot in 1963 de toenmalige conservator A. De Schrijver in contact kwam met ingenieur F.G. Lavagne van Parijs, een specialist op gebied van gewichten in het algemeen. Uit dit contact resulteerde een belangrijk dossier met de over 3 jaren lopende correspondentie tussen beide voornoemden, vooral i.v.m. de muntgewichtendozen in het Bijlokemuseum, waarbij F.B. Lavagne al zijn kennis ter beschikking stelde. De rijke informatie die dit dossier biedt, heeft er mij toe aangezet een vooropgesteld plan van deze beide wetenschapsmensen, nl. de publicatie van de muntgewichtendozen van het Bijlokemuseum, tot een werkelijkheid te maken. Inderdaad, in 1960 schijnt het contact tussen beiden afgesprongen te zijn en zijn al deze belangrijke opzoekingen geklasseerd geworden om tot in 1975 niet meer aangeroerd te worden.

Tijdens de voorstudie tot de catalogus van de tentoonstelling "Gent, 1000 Jaar Kunst en Cultuur", deel III, ben ik op het spoor gekomen van dit dossier. Nadien heb ik onmiddellijk het plan opgevat dit dossier te bestuderen en als vertrekbasis voor de gehele studie van de muntgewichtendozen in het Bijlokemuseum aan te wenden. Ik wil hier dan ook mijn welgemeende dank betuigen aan deze grondleggers van het artikel, uit wiens gegevens ik zo rijkelijk heb mogen putten.

De totstandkoming van dit artikel dank ik eveneens aan Conservator A. Van den Kerkhove die mij de kans bood deze voorwerpen te bestuderen.

Met dit artikel ligt het geenszins in mijn bedoeling een catalogus te brengen van alle muntgewichtendozen in de verzameling van het Bijlokemuseum. Slechts 24 dozen kwamen in aanmerking om de typologische aspecten van de muntgewichtendozen exact te kunnen schetsen. De overige dozen stellen ons voor hypothesen door hun onvolledigheid of door het gebrek aan identificatiemateriaal. 
Deze 24 muntgewichtendozen heb ik typologisch bestudeerd, daar ik niet. bij kunde ben de numismatische zijde ervan te beschouwen. Dit laat ik welwillend over aan een numismaat. Mijn bedoeling ligt vooral hierin deże collectie kenbaar te maken bij het publiek, het de muntgewichtendoos te leren kennen in zijn vorm en inhoud, ze te leren identificeren op. grond van de typologische kenmerken.

De hier' beschreven muntgewichtendozen zijn allen nauwkeurig geïdentificeerd. Ze konden aldus 'benaderd worden volgens een topografische indeling waarin ze chronologisch worden voorgesteld.

Deze topografische indeling beperkt zich tot drie landen, nl. Duitsland, de Zuidelijke en de Noordelijke Nederlanden. De meeste dozen dateren uit de $17 \mathrm{de}$ en de $18 \mathrm{de}$ eeuw, de bloeiperiode van het muntgewicht- en balansmaken qua vervaardigingstechnieken en productie:

Als handleiding voor een dergelijke studie dient men vooreerst het handboek van A. Dieudonné, Manuel des poids monétaires, Parijs 1925 ter hand te nemen. Hierin wordt de geschiedenis van het ijkwezen sinds de oudste tijden en in alle gebieden behandeld, en een classificatie gebrächt van: de muntgewichtendozen volgens hun soort en hun herkomst. Plaatsgebonden maar zeer grondig zijn de werken van $B . K i s c h, G e$ "wicbte- und. Waagemacher im alten Köln (16.-19. Jabrbundert), Keulen 1960 , en van K.M.C. Zevenboom - D.A. Wittop Koning, "Nederlandse Gewichten, stelsels, ijkwezen, vormen, makers en merken, Leiden 1953, waaruit ik de gegevens over de Duitse en Noordnederlandse muntgewichtendozen heb geput.

Hiernaast dienen de artikels van G. Brunin, A. de Witte, A. Visart de Bocarmé, P. Burguburu, A. Mabieu en C. Gilleman-A. Van Werveke, verschenen in de Revue Belge de Numismatique tussen 1894 en 1939, geraadpleegd te worden voor wat de Zuidelijke Nederlanden betreft.

\section{ALGEMEEN OVER MUNTGEWICHTENDOZEN}

Om de in omloop zijnde gouden en zilveren munten naar gewicht te controleren, gebruikte men reeds sinds de Oudheid een minuscuul balansje en als tegengewichten geelkoperen of bronzen gewichtjes waarvan het gewicht overeenkwam met dit van de muntstukken. Het verschil in gewicht werd bepaald met de azen, kleine dunne geelkoperen of loden plaatjes van verschillende gewicht. Deze muntgewichten, azen en balans werden in een doos bewaard, de z.g. muntgewichtendoos.

De vermelding van de algemeen geldende karakteristieken van een dergelijke doos omvat aldus een beschrijving van :

- de doos: materiaal en versiering, afmetingen, sluitingswijze, vakindeling en vervaardiger.

- het (eventuele ) etiket van de balans- en gewichtenmaker.

- de balans, vooral wat betreft de vorm en de afmetingen van de schaaltjes en eventuele merktekens. 


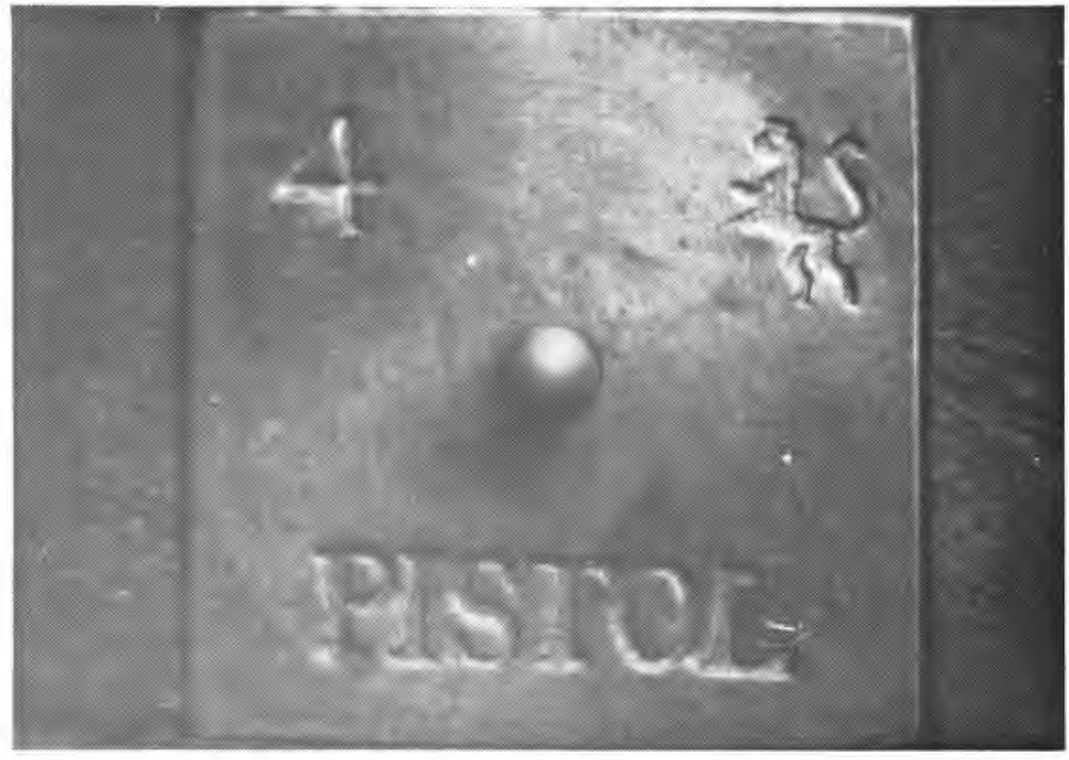

P1. 1. a) Het provinciemerkteken van Hannover: het paard, inv. 3064 


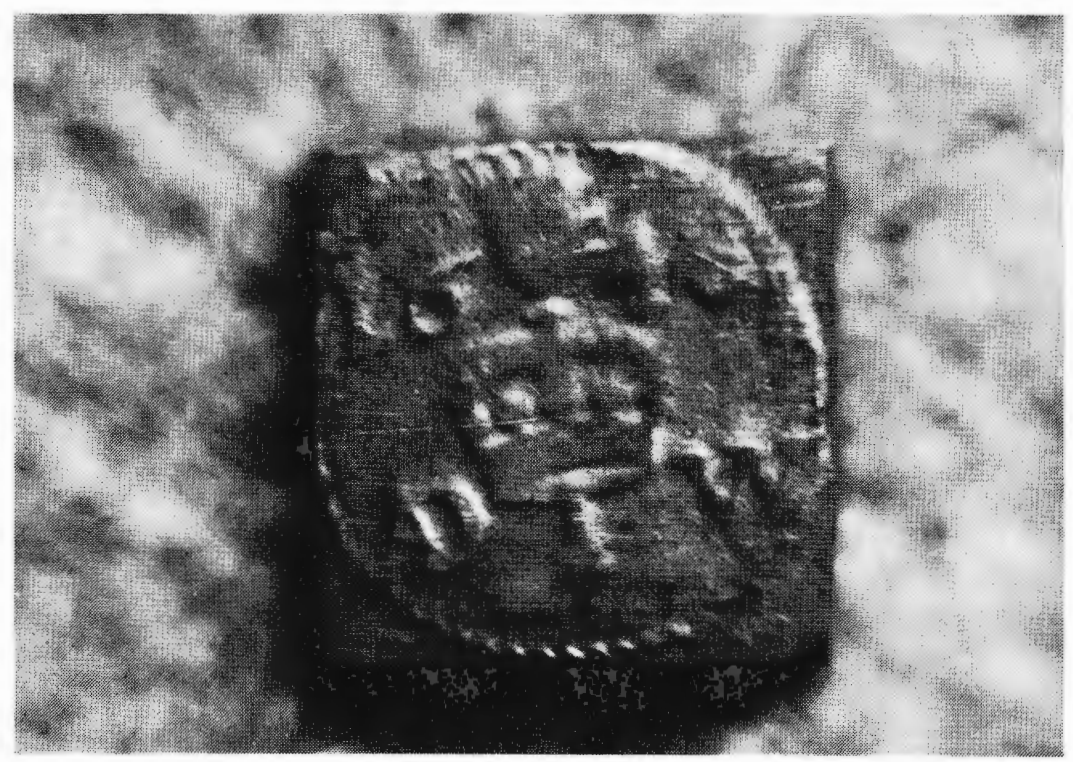

PI. 1. b). - Meestermerkteken van Aertus van Dunwalt, inv. 3055. 
- de gewichten : afmetingen, vorm, eventuele muntafbeeldingen of -benamingen en merktekens, en hun aantal.

Wat de azen aangaat, volstaat het het aantal te preciseren.

Vermits onze studieobjecten de meest karakteristieke en meeste releverende muntgewichtendozen in de verzameling van het Bijlokemuseum te Gent zijn, leggen we ons de beperking op tot het typeren van muntgewichtendozen herkomstig uit Duitslarid :en de Nederlanden, voornamelijk te situeren in de 17 de en 18 de eeuw.

\section{De doos}

De muntgewichtendoos is een plat houten kistje, vervaardigd uit verschillende houtsoorten, vooral perenhout, al dan niet versierd met uitgestoken of gegraveerde decoratieve motieven op de buiten- en binnenzijde van het deksel.

De afmetingen van deze doosjes variëren van ca. 10 dे $20^{\circ} \mathrm{cm}$ lang; ca. 7 à $10 \mathrm{~cm}$ breed en ca. 2 à $3 \mathrm{~cm}$, hoog.

Typerend voor de localisatie van deze-doosjes is eveneens- de sluitingswijze, bij middel van één of twee - zelden meer - sluithaken van verschillende vormen.

De gewichtjes en de balans bevinden zich in uitgediepte vakjes in de doos, precies beantwoordend aan de afmetingen van de gewichten en de balans. Deze vakindeling is meetkundig berekend als de dozen op voorhand gemaakt worden. De gewichten die er dan in zullen opgeborgen worden, moeten dan allemaal van dezelfde lengte en breedte zijn, maar, om het verschil in gewicht te verkrijgen, van verschillende hoogte, zodat bij ingebruikneming de vakjes enkel nog moeten uitgediept worden. Indien niet, is de vakindeling afhankelijk van wat de doos zal moeten bevatten. In dit geval worden de afmetingen en de schikking van deze vakken vooral bepaald door de afmetingen, de vorm en het aantal van de gewichten.

Voor alle dozen geldt steeds dat het vak voor de balans in het midden wordt voorzien. Links en rechts hiervan bevinden zich dan de vierkantige uitgediepte vakjes voor de muntgewichten en gewoonlijk uiterst rechts in de doos het vakje met houten schuifdeksel of geelkoperen klapdeksel voor de azen.

Een groot aantal gewichtjes kan soms veroorzaken dat een bijkomende schuiflade voor de gewichten moet aangebracht worden. Deze schuiflade bevindt zich ofwel in het deksel, ofwel onderaan in de doos.

Deze kistjes werden niet door de balans- en gewichtenmaker vervaardigd, maar door een scbrijnwerker, die soms zijn merkteken inbrandt in de doos. Het voorkomen van een dergelijk merkteken kan zeer nuttig zijn voor het bepalen van de herkomst van de doos, alhoewel talrijke schrijnwerkersmerken nog niet geïdentificeerd zijn. De inhoud van de doos (balans en gewichten) alsook het - meestal aangebrachte - etiket van de balans- en gewichtenmaker zijn geen zekere maatstaven voor de localisatie van het gehele voorwerp. Meer dan eens kon worden vastgesteld 
- mede dank zij deze schrijnwerkersmerken - dat de dozen op voorhand vervaardigd werden en geïmporteerd of geëxporteerd werden. Dergelijke schrijnwerkersmerken mogen niet verward worden met het ingebrande controlemerk dat men op de Rijnlandse dozen aantreft.

\section{Het etiket}

De meeste inlichtingen over de balans- en gewichtenmaker worden ons verstrekt door zijn etiket dat op de binnenzijde van het deksel van de muntgewichtendoos gekleefd wordt. De houtgravure op dit etiket biedt ons steeds geijkte voorstellingen i.v.m. het muntwezen of de wisselmarkt, bekroond met de stadswapens. In het opschrift onderaan wordt ons de identiteit van de vervaardiger van de gewichten en de balans medegedeeld. Daarnaast wordt veelvuldig een bijbelcitaat aangehaald, zinspelend op het taboe van de vervalsingen in het ijkwezen, alsook een devies van de gewichten- en balansmaker. De meeste plaats op het etiket wordt evenwel voorbehouden aan de afbeeldingen en de naam van de munten waarmee de gewichten in de doos moeten corresponderen.

Naast dit etiket treft men ook aan dat de naam van de corresponderende munt in inkt boven het gewichtenvakje wordt bijgeschreven.

\section{De balans}

De hier beschouwde balansjes zijn steeds uit staal vervaardigd met aan de armen twee touwtjes waaraan geelkoperen schaaltjes hangen. De schaaltjes kunnen allebei rond zijn van vorm of rond en driehoekig. Voor ons is het steeds interessant indien er op één van deze schaaltjes een meestermerkteken voorkomt.

De diameter van de ronde schaaltjes varieert tussen 3 à $5 \mathrm{~cm}$., de zijde van het gelijkzijdig driehoekig schaaltje tussen $3,5 \gtrsim 6 \mathrm{~cm}$.

\section{De gewicbten}

De afmetingen van het bovenvlak van de muntgewichten ligt tussen ca. $1,3 \mathrm{~cm}^{2}$ en $1,9 \mathrm{~cm}^{2}$. Een doos bevat ofwel gewichten met hetzelfde bovenvlak maar met verschillende hoogte, ofwel met totaal verschillende afmetingen maar steeds begrepen tussen beide aangehaalde uitersten, naargelang de gewichten gemaakt worden naar de vorm van de vakjes in de doos of omgekeerd.

Van vorm zijn het blok- of knopgewichten, vierkantig van bovenvlak, taps aflopend naar het ondervlak toe.

In de $17 \mathrm{de}$ eeuw geldt algemeen dat de corresponderende munt wordt afgebeeld op de bovenzijde van het gewicht In de 18de eeuw treft men hiernaast ook gewichten aan waarop enkel de naam van de munt wordt vermeld, nl. op de knopgewichten.

De gewichtjes bieden ons de meeste merktekens. Deze kunnen zijn : het meestermerkteken van de balans- en gewichtenmaker of ijker, het stadsmerkteken en het provinciemerkteken. De verplichting tot het aanbrengen 
van deze merktekens is niet steeds nagekomen of bestond zelfs helemaal niet of slechts gedeeltelijk.

Het aantal der gewichten in een doos zonder schuiflade bedraagt 7, 13 of 18 gewichten; in een grote doos 40 . In dozen met een schuiflade in het deksel bevinden zich 5 gewichten in de doos en 8 in de schuiflade. Dozen met een schuiflade onderaan in de doos bevatten $9+10$ gewichten in de schuiflade, of $10+15$ gewichten in de schuiflade, of $13+18$ gewichten in de schuiflade.

\section{TYPOLOGIE VAN DE MUNTGEWICHTENDOZEN VOLGENS HUN HERKOMST}

\section{Duitsland 1}

De meeste van de gekende Duitse dozen zijn van Rijnlandse herkomst : Keulen, Barmen, Lennep en Wichlinghausen. Keulen vooral kende vanaf de $16 \mathrm{de}$ eeuw een bloei in het balans- en gewichtenmakersambacht, waaraan $\mathrm{B}$. Kisch ${ }^{2}$ een zeer goede gedocumenteerde en geilllustreerde studie gewijd heeft.

Opmerkelijk is dat de Keulse muntgewichtendozen zich onderscheiden van deze uit de andere Rijnlandse steden, niet alleen qua constructie, maar ook qua inhoud, merktekens en balansvormen. Vermits de verzameling muntgewichtendozen in het Bijlokemuseum beide types representeert, houden wij eraan hier uitgebreid op het onderscheid in te gaan.

\section{a) Keulen}

De 18de eeuwse Keulse dozen gelijken sterk op de Vlaamse ${ }^{3}$. Hun afmetingen bedragen $\mathrm{ca} .12 \mathrm{~cm}$ in lengte, ca. $6,6 \mathrm{~cm}$ in breedte en ca. $3 \mathrm{~cm}$ in hoogte. Ze zijn dikwijls versierd met ornamenten, ingekerfd met de holle beitel. Typisch voor de Keulse exemplaren is de schuiflade voor muntgewichten die zich in het deksel van de doos bevindt. De sluiting van de doos wordt verzekerd door één haakslot.

De vakindeling in de doos is steeds identisch : één groot vak in het midden voor de balans; vijf vakjes (verschillend in afmetingen) voor de gewichten, en één schuiflade rechts in de doos voorbehouden voor de azen. In de schuiflade in het deksel bevinden zich steeds acht gelijke vakjes, regelmatig geordend.

Op de binnenzijde van het deksel treft men steeds het etiket aan van de muntgewichten- en balansmaker met een opschrift vermeldend de naam, het adres en de hoedanigheid van de maker, alsook de datering (gedeeltelijk of volledig).

(1) F. LAVAGNE, Les Boîtes de changeurs du musée d'histoire de Berne, Scbweizer Münzblätter, 16, 1966, heft 61, pp. 43-45.

(2) B. KISCH, Gewichte- und Waagemacher im Alten Köln (16.-19. Jahrhundert), Keulen, 1960.

(3) Zie p. 10. 
De Keulse balans wordt gekarakteriseerd door de vorm van de schaaltjes : een rond en een driehoekig. Op dit laatste bevindt zich het meestermerkteken.

De gewichtjes hebben allen verschillende afmetingen variërend tussen 15 à $18 \mathrm{~mm}^{2}$ als bovenvlak. Ze zijn vierkantig-piramidaal van vorm. De gedeeltelijke of volledige naam van de ermee corresponderende munt wordt boven het vakje van het gewichtje vermeld in zwarte inkt. Op de bovenzijde van elk gewichtje bevindt zich dan de afbeelding van de munt. Als vaste maatstaf voor de herkenbaarheid van Keulse muntgewichten geldt de blanco gehouden keerzijde.

\section{KEULSE MUNTGEWICHTENDOZEN IN DE VERZAMELING VAN HET BIJLOKEMUSEUM}

De oudste doos (inv. 3062) dateert van 1584 (ingegraveerd in het deksel). Haar afmetingen bedragen $18 \mathrm{~cm}$ in lengte, $9,5 \mathrm{~cm}$ in breedte en $3 \mathrm{~cm}$ in hoogte. Aan weerszijden van het balansvak

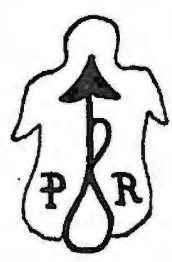

afb. 1 bemerkt men een schrijnwerkersmerkteken dat men tot $\mathrm{nu}$ toe slechts op de muntgewichtendozen van $\mathrm{H}$. Dassel van Keulen heeft aangetroffen ${ }^{*}$ (afb. 1). De zorgvuldige en prachtig uitgestoken renaissance-versiering aan de buiten- en binnenzijde van het deksel, herinnert aan de boekbandversiering uit deze periode. Spijtig is te moeten vaststellen dat alle gewichten en azen ontbreken en dat van de balans slechts twee ronde schaaltjes zonder merkteken zijn overgebleven. Het schrijnwerkersmerkteken, de datering en de constructie van deze doos wijzen zonder twijfel naar Keulen, terwijl de balans naar andere Rijnlandse steden wijst ${ }^{5}$.

Tussen 1636 en 1652 was er in Keulen een Berndt Odendal (Odendall

- Odenthal) werkzaam als balansmaker ${ }^{6}$. In 1655 wordt zijn weduwe vermeld in de archieven. Van hem bezit het Bijlokemuseum een balansje, behorend tot doos inv. $2173^{\text {? }}$.

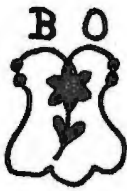

afb. 2 Dit balansje - waarvan de naald ontbreekt - heeft een rond en een driehoekig schaaltje. Dit laatste draagt het merkteken van Berndt Odendal (afb. 2).

De resterende Keulse dozen dateren allen uit de $18 \mathrm{de}$ eeuw en zijn het werk van twee Keulse balansen/of gewichtenmakers, nl. Casper Grevenberg (1703$\dagger 1738$ ) en Joan Kirch (1735-† 1777).

Caspar Grevenberg (Graevenberg, Grevenbergh, Grie-

berg) was een lid van een Keulse familie die nog drie andere meesterbalansmakers telde, nl. Jacob (1730-1765), Johann (1735-1753) en Michel

(4) B. $\mathrm{KISCH}$, op. cit., afb. 45 en 46 ; taf. III, 31.

(5) Zie pp. 8-10.

(6) B. KISCH, op. cit., pp. 101-102.

(7) Zie ook pp. 12-13. 
(1750). Hij werd voor het eerst als meester-balansmaker aangetroffen in 1703. Op 17 februari 1710 werd hij tot ijkmeester benoemd, als opvolger van Jacob Medtmann. Hij bezat eveneens de titels van stadsbalansmaker en -balansmeester ${ }^{8}$.

De doos van zijn hand (inv. 3060) is $12,4 \mathrm{~cm}$ lang, $6,7 \mathrm{~cm}$ breed en $3,4 \mathrm{~cm}$ hoog. Het deksel is versierd met ingebrande motieven. In de doos, links en rechts van het balansvakje en zes maal op de buitenzijde van het deksel, bemerkt men een ingebrand schrijnwerkersteken of -ornament ${ }^{\theta}$, in de vorm van een gestileerde bloem. Op de buitenzijde van de doos, in het centrum, het niet meer te identificeren schrijnwerkersmerkteken.

Het etiket op de binnenzijde van het deksel stelt in het centrum bovenaan de wapens van Keulen voor, waaronder een cartouche met de gothische inscriptie: „Recht Abgezogene wag / und gewicht / Macht M : Caspar Grevenberg / der Statt Cöllen geschworner / ijch M Wohnet unter teschen Macher AnnO". Links hiervan, het Geweten met fakkel en balans, waarachter de Dood met sikkel

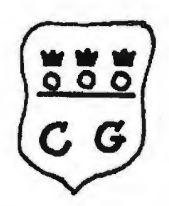

afb. 3 en zandloper. Rechts, de geblinddoekte Justitia met zwaard en balans.

Op het driehoekig balansschaaltje werd het meestermerkteken van Caspar Grevenberg als stadsijker aangebracht ${ }^{10}$ (afb. 3).

De gewichten in de schuiflade zijn voltallig, nl. 8 . In de doos ontbreekt er één van de vijf gewichten. In de schuiflade in de doos bevinden zich drie azen. Joann (Johannes-Iann) Kirch (Kürch) was Keuls balansmaker van 1737 tot 1777 en stadsijker sedert 20 juli 1781 . In oktober 1753 werd hij tot balansijkmeester benoemd 11 .

Het Bijlokemuseum bezit drie muntgewichtendozen van Joann Kirch (inv. 3842, 2176, 3061), waarin we een aantal identieke kenmerken terugvinden.

De doosjes vertonen allen op het deksel een ingekerfde versiering identisch bij dozen inv. 3842 en 2176 die ook vijf schrijnwerkerstekens of -ornamenten in de vorm van een gestileerde bloem vertonen op de buitenzijde van het deksel. De deksels bevatten aan de binnenzijde een schuiflade waarop bet etiket is gekleefd. De houtgravure stelt bovenaan in het midden de stad Keulen voor, links een boer met een vlegel en rechts een boerin met een kroon in de linkerhand. In het midden, het opschrift : „Recht Abgezohene Wag und / Gewicht macht meister Iann / Kirch wöhnhaft unter Klein / Tesche macher im Gulten Pril / tegen der klein Boltegassen / über in Cöllen Aô 17"'12. Boven de vakjes zijn de namen van de corresponderende munten in zwarte inkt bijgeschreven.

(8) B. KISCH, op. cit., p. 67 en pp. 85-88.

(9) Cfr. B. KISCH, op. cit., afb. 23.

(10) B. KISCH, op. cit., taf. I,11 en afb. 22.

(11) ID., p. 93.

(12) De onvolledigheid van het jaartal toont nogmaals aan dat de dozen op voorhand vervaardigd werden. 
Slechts de gewichtsinhoud in deze dozen verschilt.

Van de balans van doos inv. 3061 (PL 2) (11,8 cm lang x 6,7 cm breed $\times 2,9 \mathrm{~cm}$ hoog) is de wijzernaald gedeeltelijk afgebroken. Op het driehoekig balansschaaltje treft men het meestermerkteken aan van Kirch ${ }^{13}$ (afb. 4). De gewichten in de

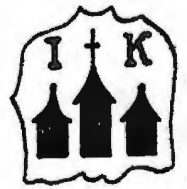

afb. 4 schuiflade zijn voltallig. In de doos ontbreekt er één van de vijf gewichten. Het aantal azen beperkt zich tot vier.

Van doos inv. $3842(12 \mathrm{~cm}$ lang $x 6,7 \mathrm{~cm}$ breed $\mathrm{x}$ $2,8 \mathrm{~cm}$ hoog) ontbreekt het haakslot. De balans behoort niet tot de doos : ze is te groot voor de. beschikbare ruimte ; de schaaltjes zijn niet gemerkt zoals gebruikelijk te Keulen. In de schuiflade in het deksel ontbreken drie gewichten. De schuiflade voor de azen alsook de azen ontbreken eveneens. De doos zelf bevat vier van de vijf gewichten.

Van doos inv. $2176(12,2 \mathrm{~cm}$ lang $\times 6,6 \mathrm{~cm}$ breed $\times 2,8 \mathrm{~cm}$ hoog) ontbreekt eveneens de sluithaak. De balans is identisch aan deze uit doos inv. 3061. In de doos ontbreekt eén van de vijf gewichten. De acht gewichten in de schuiflade in het deksel zijn voltallig. De schuiflade in de doos bevat zes azen.

b) Rij n land

Niet alleen geldend voor de verzameling Rijnlandse dozen in het Bijlokemuseum, maar algemeen gangbaar is het feit dat de Rijnlandse dozen jonger zijn dan de Keulse (na 1760). Hun afmetingen bedragen ca. 18 $\mathrm{cm}$ lengte, $9 \mathrm{~cm}$ breedte en $2,3 \mathrm{~cm}$ hoogte. Op geen enkele doos treffen we een schrijnwerkersmerkteken aan. De dozen sluiten met twee sluithaken, zijn onversierd en bruin of zwart geverfd. Steeds voorkomend - en zich hierdoor nogmaals onderscheidend van de Keulse dozen - is het controlemerk dat aan de binnenzijde van het deksel wordt ingebrand. Deze merken beperken zich tot de woorden "IUSTIRT" (betekenis : geijkt?) en "J.CVMAGZ" (betekenis?).

Het etiket vermeldt enkel de naam, het adres en de hoedanigheid van de balans- en gewichtenmaker, en het jaartal (gedeeltelijk of volledig). Het enige identificatiemateriaal dat de Rijnlandse dozen ons biedt is dit etiket.

De vakindeling in de doos is dezelfde als in de Keulse dozen, behalve dat er zich geen schuiflade in het deksel bevindt, dat de schuiflade voor de azen vervangen is door een geelkoperen klapdeksel en dat er in de doos 18 gewichtenvakken voorzien zijn. Deze vakken zijn even groot op één vak na, maar verschillen in diepte.

De vierkantig-piramidaalvormige gewichten variëren in afmetingen van 15. tot $18 \mathrm{~mm}^{2}$ als bovenvlak. Ze zijn voorzien van een knopje waardoor aan de binnenzijde van het deksel cilindervormige gaatjes werden angebracht waarin de uitstekende knopjes passen. Op de bovenzijde van ieder

(13) B. $\mathrm{KISCH}$, op. cit., taf. I,25. 
gewicht wordt het provinciemerkteken aangebracht. De naam van de munt (volledig of gedeeltelijk) bevindt zich op de bovenzijde van ieder gewicht en wordt met rode inkt boven het betreffende gewichtenvakje herhaald. Zoals te Keulen treft men op de gewichten geen meestermerk aan, noch op één van de twee ronde balansschaaltjes.

\section{RIJNLANDSE MUNTGEWICHTENDOZEN IN DE VERZAMELING VAN HET BIJLOKEMUSEUM}

Het Bijlokemuseum is vier Rijnlandse dozen uit de $18 \mathrm{de}$ eeuw rijk, nl. van Johann Peter Braselmann (1770-1783), Johann Peter Aeckerberg (1754-1795) en Johann Daniel vom Berg (1778-1799).

Jobann Peter Braselmann was een balansmaker en gezworen ijkmeester van Wichlinghausen in Oberbarmen. Zijn doos inv. $3064(18 \mathrm{~cm} 1$ x $9 \mathrm{~cm}$ b $\times 2,3 \mathrm{~cm} \mathrm{~h}$ ) is bruin geverfd aan de buitenzijde en vertoont aan de binnenzijde van het deksel een etiket met het opschrift: "Waag und Gewicht / macht / von Ihro Chursïrstl. Durchl. / zu Pfaltz / gnädigst privil. examinirt und / geschworner Ichtmacher / JOH. PET. BRASELMANN, / auf Wichlinghausen in Oberbarmen. 177 ". In de rechterbenedenhoek van het deksel, het controlemerk „IUSTIRT”. Twee van de gewichten ontbreken. Er zijn vier azen voorhanden. Op de bovenzijde van de gewichten, het provinciemerkteken, nl. het paard van Hanover (PL. 1a). Eén gewicht vertoont hiernaast ook een zonnetje (?).

Jobann Peter Aeckersberg verwierf dezelfde titels als voorgenoemde. Hij oefende eveneens zijn beroep uit te Wichlinghausen. Zijn doos inv. 3063 vertoont dezelfde kenmerken als deze van Braselmann. De tekst op het etiket luidt : „Waag und Gewicht / macht / von Ihro Chursl. Durchl. / zu Pfaltz / gnädigst privil. examin. / und geschworner / IchtMacher / J.P. AECKERSBERG, / auf Wichlinghausen im / OberBarmen. 1782". Het cijfer twee van de eenheid in het jaartal werd bij voltooiing van de gewichten en de balans in rode inkt aangevuld op het etiket. Ook zijn gewichten zijn dezelfde als deze van Braselmann, op het provinciemerkteken na dat hier de leeuw van Palatinat is. De doos inv. $3838(18 \mathrm{~cm} 1 \times 9,5 \mathrm{~cm} \mathrm{~b} \times 2,3 \mathrm{~cm} \mathrm{~h})$, waarvan het etiket verdwenen is, hebben we op basis van vergelijking toegeschreven aan Aeckerberg. Van het balansje in deze doos zijn de touwtjes alsook de schaaltjes verdwenen. Zeven azen en zestien gewichten bleven gespaard. Van één gewichtje ontbreekt het knopje.

Jobann Daniel vom Berg bezat eveneens dezelfde titels als zijn voorgenoemde collega's. Hij pratikeerde echter in Lennep. Bij hem treffen we steeds het controlemerkteken ,J.CVMAGZ" aan op de doos. Het etiket in zijn bruingeverfde doos inv. $2084(18 \mathrm{~cm} 1 \times 9 \mathrm{~cm} \mathrm{~b} \times 2,1 \mathrm{~cm} \mathrm{~h})$ vermeldt de inscriptie : „Diese geächte Waag und Gewicht / macht / (v)on Ihro Chursürstl. Durchl. / zu Pfalz-Bayern / gnädigst privilegirt und geschworner / JOHANN DANIEL VOM BERG, / in der Bergischen Hauptstadt Lennep, 1787". Er ontbreken drie gewichten in deze doos. Op 14 ervan werd het provinciemerkteken van Hanover, nl. het 
paard, ingestempeld; één gewicht bezit geen merktekens en twee gewichten vertonen het paard en een zonnetje (?). De doos bevat slechts één aas.

\section{De zuidelijke Nederlanden ${ }^{14}$}

Zoals reeds hoger aangestipt gelijken de Vlaamse muntgewichtendozen sterk op de Keulse uit de $18 \mathrm{e}$ eeuw.

De Vlaamse dozen onderscheiden zich dikwijls door hun gemoulureerde zijkanten. Ze zijp ook groter. Ze sluiten met één of twee sluithaken en zijn al dan niet versierd.

De vakindeling in de doos is gelijkaardig aan de Keulse, maar de Vlaamse dozen bevatten een groter aantal gewichten, variërend van 13 tot 18 gewichten in de doos. I.p.v. .een schuiflade voor gewichten in het deksel, bevindt deze zich hier onderaan in de doos. Deze lade kan 12, 15 of 18 gewichten bergen. De vakjes in de doos zijn niet steeds bestemd om één gewicht te bevatten. Herhaaldelijk worden verschillende gewichten, corresponderend met dezelfde munt, in eenzelfde vakje aangetroffen.

Het enige aan te halen verschil tussen een Keulse en een Vlaamse balans is dat op. de Vlaamse meestal het meester- en stadsmerk voorkomt.

De Vlaamse gewichten zijn van dezelfde vorm als de Keulse, en vertonen aan de bovenzijde eveneens de afbeelding van de corresponderende munt, maar aan de keerzijde het meester- en stadsmerk.

Het merendeel van de Vlaamse dozen in de verzameling van het Bijlokemuseum is herkomstig van Antwerpen. Daarnaast bezit het museum één Brugse en één Gentse doos. Wat Gent betreft, zullen we ons niet beperken tot deze ene doos, maar iets uitgebreider ingaan op de Gentse muntgewichten- en balansmakers van wie we inlichtingen bezitten die een periode van twee eeuwen bestrijken, waarin ons acht muntgewichtenen balansmakers gekend zijn.

\section{a) Antwerpen ${ }^{15}$}

Er is weinig of geen onderscheid te maken tussen de Vlaamse dozen onderling. Men kan ze slechts exact localiseren aan de hand van het etiket en de merktekens.

Het stadsmerkteken van Antwerpen is door de eeuwen heen steeds hetzelfde gebleven, nl. de open rechterhand met de handpalm naar boven, symbool van de legende van Antigoon. Deze kan dan vergezeld zijn van andere symbolen zoals bv. de hamer (teruggaand op het wapenschild van het smedenambacht waarvan de muntgewichten- en balansmakers deel uitmaakten), de eikel, het vlammend zwaard, de koningskroon e.a. Dit geheel is steeds beschreven binnen een cirkel en omvat eveneens de meesterinitialen en het jaartal.

(14) F. LAVAGNE, Les Boîtes de changeurs du musée d'histoire de Berne, Scbweizer Münzblätter, 16, 1966, heft 61, p. 46.

(15) A. DIEUDONNE, op. cit., pp. 160-161. 


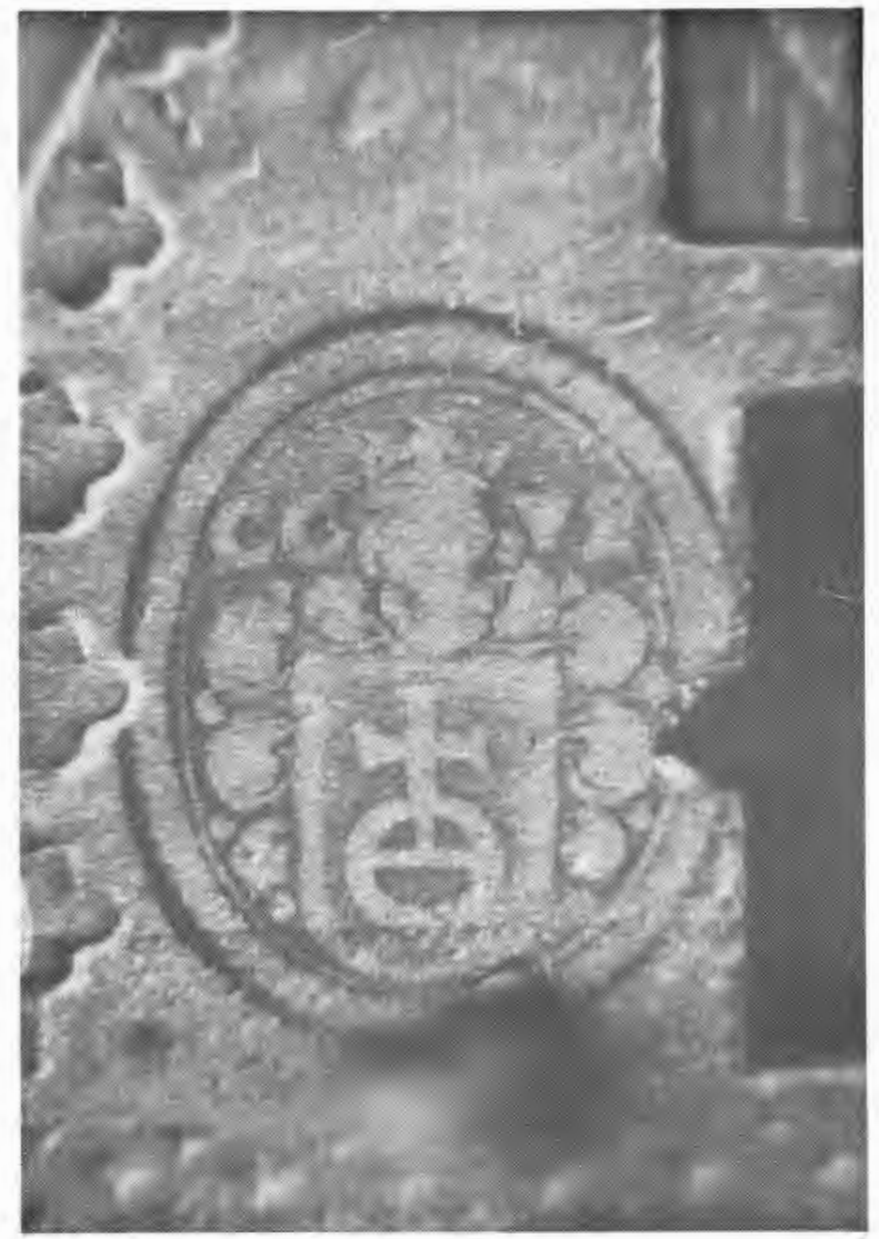

P1. 1. c) Niet-geïdentificeerd schrijnwerkersmerkteken, inv. 2173 


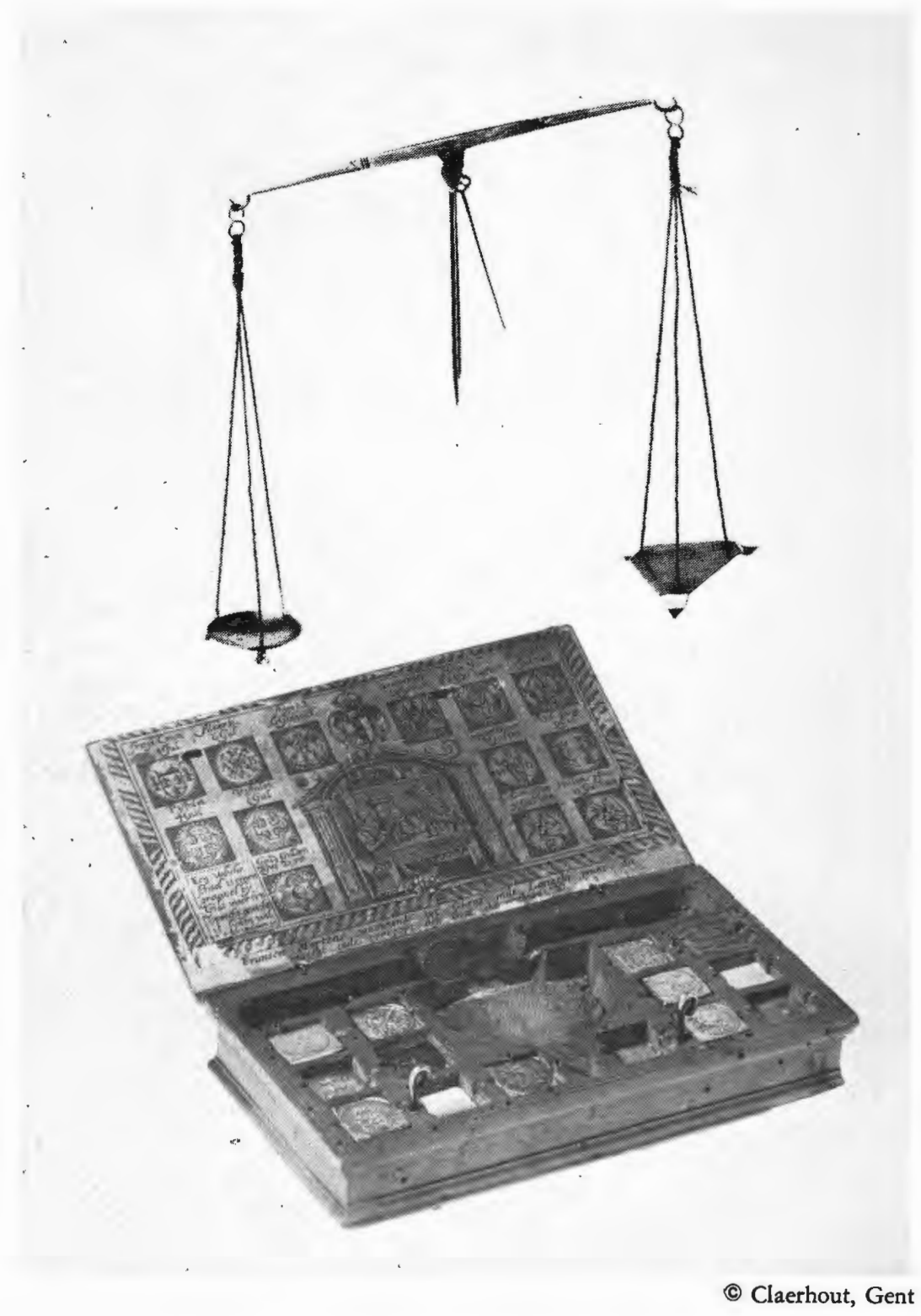

Pl. 2. - Muntgewichtendoos van F. Martens, Gent, inv. 3056 


\section{ANTWERPSE MUNTGEWICHTENDOZEN IN DE VERZAMELING VAN HET BIJLOKEMUSEUM}

De oudste Antwerpse dozen (inv. 3055 en 3058) in de verzameling van het Bijlokemuseum, zijn deze van Aertus, Gerard en Peter van 'Dunwalt. Verschillende Dunwalt's waren actief te Antwerpen in dit betoep: Gerard (1641-1644); Aertus (ten onrechte soms Arnold of Arthur. genoemd (1647-1650); Jean-Frédéric (1654) en .Peter (Pieter) (1699).

De respectievelijke afmetingen van deze dozen

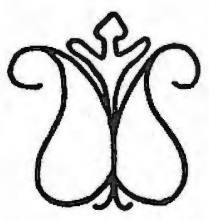

afb. 5 bedragen : $16 \mathrm{~cm} 1 \times 9 \mathrm{~cm} \mathrm{~b} \times 3,7 \mathrm{~cm} \mathrm{~h}$ (inv. $3055)$ en $15,7 \mathrm{~cm} 1 \times 8,5 \mathrm{~cm} \mathrm{~b} \times 3,4 \mathrm{~cm} \mathrm{~h}$ (inv.3058). Beide dozen zijn versierd met een gegraveerde versiering. Doos inv. 3055 draagt nog sporen van een lichtblauwe beschildering. Doos'inv. 3058 vertoont een niet-geïdentificeerd schrijnwerkersmerkteken, links en rechts van het balansvakje (afb. 5).

Op de binnenzijde van de deksels is een etiket gekleefd met een houtgravure voorstellende een win-

keltje met een handelaar. Man en vrouw zitten aan een tafeltje hun geld te tellen, terwijl de Dood hen bedreigt met een lans en hun levensuren aftelt met een zandloper. Rechts'van het tafereeltje, Justitia met zwaard en balans, waarboven een engel.vliegt die haar een bladkroon boven het hoofd houdt. Boven deze voorstelling, de wapens van de stad Antwerpen. In de rechterbenedenhoek, het opschrift. Dit van doos inv. 3055 luidt : „Aertus van Dunwalt maeckt / ende vercoopt dese Goutgewichte / op den hoeck vande oude Borse /. inde Croone "tot. Antw.(erpen)" (etiket beschadigd). Dit van doos nv. 3058 luidt : „Peeter van Dunwalt maeckt / ende vercoopt dese Gontgewichte / op dé eyermert / : inde Roos tot Antwerpen." Onderaan, een tweede opschrift, gelijkluidend in beide dozen : „ORDINASTI Vande connich luche maiestijt is dat alle goud sal moten met /: raesen Remedie int huysken staen ende wat minder is moet Betalen betalen voor de aes 2 st. Nij. 1648'. Op de resterende ruimte zijn zestien verschillende: munten afgebeeld, 'telkens vergezeld van hun naam.

In de doosjes zijn een aantal vakken voorzien : één groot in het midden voor de balans; dertien kleine voor de muntgewichten en één vakje "met schuifdeksel voor de

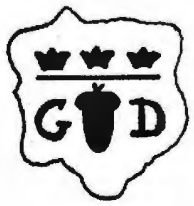

afb. 6 azen. Onderaan in' de. dozen bevindt zich een schuiflade voor achttien"muntgewichten.

Het drieboekig balansscbaaltje inv. 3055 is gemerkt door Gerard van Dunwalt (afb. 6) met zijn initialen $G$ en $D$ waartussen een eikel, bekroond met drie Keulse kronen ${ }^{16}$. Deze kronen laten vermoeden dat er een Keuls balansmaker aan de oorsprong van de Dunwalt-familie zou gestaan hebben. Er is een

(16) A. VISART DE BOCARME, Notes sur quelques ajusteurs des Pays-Bas, Revue Belge de Numismatique, 1939, p. 93 ; B. KISCH, op. cit., taf. I,3. 
Duits balansmaker uit Hamburg bekend, nl. Gerhardt Dünewald, actief in 1666.

Elk vakje in doos inv. 3055 bevat één gewicht, op één vakje na dat er twee bevat. De vakjes zijn echter niet tot boven toe gevuld, zodat een tiental gewichten schijnen. te ontbreken. De achttien gewichten in de schuiflade onderaan zijn voltallig. De schuiflade in de doos bevat vijf azen. Alle gewichten dragen op de keerzijde het meestermerkteken van Aertus van Dunwalt ${ }^{17}$ : zijn initialen A-D-W- en het gesplitste jaartal 1648, het stadsmerk van Antwerpen met de hand, de koningskroon en de eikel (Pl. 1 b).

In doos 3058 zijn twee gewichtenvakjes leeg in de doos; één vakje is niet tot boven toe gevuld zodat hier waarschijnlijk één gewichtje ontbreekt; in de schuiflade onderaan zijn slechts acht van de zestien gewichten bewaard gebleven. In de schuiflade in de doos bevinden zich acht azen. Alle gewichtjes vertonen op de keerzijde eveneens het merkteken van Aertus van Dunwalt maar met het jaartal 1650.

Zeventiende-eeuws is ook doos inv. 2173, vervaardigd door de Antwerpse balansmaker en ijker, Pieter Herck II. Er is in Antwerpen een Pieter (of Pierre) Herck gekend - hij wordt Pieter Herck I genoemd - van wie gewichten gekend zijn daterend 1617. Zijn merkteken ontmoet men niet meer vanaf 1645 . Wel vindt men vanaf dat jaar talrijke gewichten gedateerd $1647,1648,1649,1650,1655$ en 1667 , met als meest recente datering 1691. Er moeten dus twee balansmakers met deze naam geweest zijn : Pieter Herck I (1617-1645) en Pieter Herck II (1645-1691). In hoeverre Pieter Herck II nog actief was na 1691 is ons niet bekend. Tijdens zijn loopbaan als balansmaker en ijker werd hij tot Algemeen IJker van Antwerpen en Brabant en tot Meesterbalansmaker van Brabant benoemd.

In de biografie van de Brusselse balansmaker Gilles Delmotte ${ }^{18}$ leest men dat deze, naast balansmaker, in 1717 ook tot Meesterbalansmaker van de provincie Brabant werd bevorderd, en dit tot na de dood van Pieter Herck. Mogelijk is deze laatste functie vacant gebleven gedurende een lange periode : indien Herck overleed in 1717 zou zijn loopbaan, begonnen in 1645, 72 jaren geduurd hebben, wat onmogelijk blijkt.

Deze doos inv. $2173(14,7 \mathrm{~cm} \mathrm{I} \mathrm{x} 8,8 \mathrm{~cm} \mathrm{~b} \times 3,4 \mathrm{~cm} \mathrm{~h})$ vertoont op de binnen- en buitenzijde van het deksel een gegraveerde versiering. Het deksel, sluitend met twee sluithaken, hangt nu niet meer vast aan de doos. Vermits de binnenkant van het deksel versierd is, schijnt er nooit een etiket op gekleefd te zijn geweest.

In het midden van de doos bevindt zich het groot balansvak, aanvankelijk belegd met groene zijde. Rechts, één vakje met schuiflade voor de azen. Er zijn tien vakjes voorzien voor de muntgewichten. Onderaan in de doos, een schuiflade met vijftien vakjes.

(17) A. DIEUDONNE, op. cit., PL. XVI, 30 en p. $160 \mathrm{nr}$. 11.

(18) A. DE WITTE, Quelques ajusteurs jurés des poids et balances en fonctions aux Pays-Bas autrichiens durant la seconde moitié du XVIIIe siècle, Revue Belge de Numismatique, 1895, p. 72 ; ID., Les dénéraux et leurs ajusteurs aux Pays-Bas méridionaux, Revue Belge de Numismatique, 1899, pp. 78-111. 
Links en rechts van het balansvak bemerkt men een niet-geïdentificeerd scbrijnwerkersmerkteken (PL. $1 \mathrm{c}$ ), dat reeds werd aangetoffen op muntgewichtendozen van P. Herck, J.D. Bodringen (Rotterdam), Berndt Odendal (Keulen) en Matthias Medtmann (Keulen) ${ }^{19}$.

De balans is van Keulse herkomst, en werd onder het betreffende hoofdstuk besproken ${ }^{20}$.

Deze doos bevat elf muntgewichten; in één vakje bevinden er zich twee gewichten; van de andere vakjes zijn er drie niet tot boven toe gevuld, zodat er waarschijnlijk drie gewichten

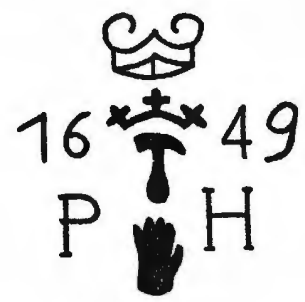

afb. 7 ontbreken. De schuiflade onderaan in de doos telt het volledige aantal van vijftien gewichten. In de schuiflade in de doos, drie azen. Alle gewichten vertonen op de keerzijde het merkteken van Pieter Herck (afb 7). Twee gewichtjes zijn gedateerd 1647, één 1648, zeven 1649 en van één kan het laatste cijfer van het jaartal niet meer ontcijferd worden.

De familienaam $W$ olschot was in Antwerpen geen onbekende naam in het ambacht der gewichten- en balansmakers. Uit deze familie werden reeds geïdentificeerd : Jan (Jean) François, vader (1726-1765) ; Jacques François, zoon (1756-1785) en Joseph François, kleinzoon, 1785. Het is niet eenvoudig aan één van hen de talrijke genoteerde merktekens toe te schrijven ${ }^{21}$. De talrijke exemplaren van muntgewichtendozen van Jan François Wolschot, verspreid over verschillende musea, tonen aan dat hij als ijker en balans- en gewichtenmaker een veel gevraagd man was. Men heeft van hem gewichten geïdentificeerd daterend van 1726 , de periode dat het beroep vrij was, en dit tot 1749. In dit jaar werd hij officieel aangesteld als ijker en balansmaker. Het is pas van die datum af dat een strengere organisatie in dit beroep werd ingevoerd. Vóór die datum werden dezelfde eisen niet gesteld voor de uitoefening van dit beroep en de toegang tot het ambacht. Deze aanstelling gebeurde op dezelfde dag als van zijn Antwerpse collega J.F. Neusts ${ }^{22}$. Jan François Wolschot heeft zijn beroep uitgeoefend tot 1765 want van dat jaar dateert het verzoek van François de Batist om hem op te volgen.

Het Bijlokemuseum bezit drie muntgewichtendozen van Jan François Wolschot (inv. 3059, 3840 en 3841). Deze drie dozen zijn onversierd en meten $15,6 \mathrm{~cm} \mathrm{I} \mathrm{x} 8,4 \mathrm{~cm} \mathrm{~b} \mathrm{x} \mathrm{2,6} \mathrm{cm} \mathrm{h} \mathrm{(inv.} 3059$ ); $16,4 \mathrm{~cm} 1 \times 9 \mathrm{~cm}$ b x 2,5 cm h(inv. 3840 ) en $16,9 \mathrm{~cm} 1 \times 8,4 \mathrm{~b} \times 2,7 \mathrm{~cm} \mathrm{~h}$ (inv. 3841 ). Van doos inv. 3840 ontbreken de scharnieren. Deze doos sluit maar met één haakslot, in tegenstelling tot de anderen.

(19) B. KISCH, op. cit., taf. III, 26.

(20) Zie p. 6.

(21) P. BURGUBURU, Les Trois Wolschot, Revue Belge de Numismatique, 1930 , p. 267.

(22) Zie p. 14. 
Alle drie dragen op de binnenzijde van het deksel een etiket met een houtgravure. Deze stelt in het midden een winkeltje voor van een ijker. Twee mannen zitten aan een tafeltje. Eén van hen hanteert de balans. Achter hen, aan de wand, een uurwerk. Bovenaan, de wapens van Antwerpen. Links en rechts hiervan, de twee delen van het jaartal : in doos inv. 3059 is dit 1730 ; in dozen inv. 3840 en 3841 is dit 1750 . Onderaan het etiket, drie opschriften. In het midden : „J. F. Wolschot geswore / ijcker van haere maiestijt / Munten en Balancen.” Links : „dese gout gewichten / moeten gewegen worden / met 2 haesen voor de remedie". Rechts ,een citaat uit de Bijbel : „Een valsche schael is eenen /Grouwel by Godt maer een oprecht /gaewecht is sijnen wille." Op de resterende ruimte zijn veertien verschillende munten afgebeeld, vergezeld van hun naam.

De drie balansjes zijn gelijkaardig van vorm. Op het driehoekig schaaltje van balans inv. 3059 werd het meestermerkteken van Gerard van Dunwalt en het stadsmerkteken van Antwerpen gestempeld ${ }^{23}$. Het balansje is hierdoor niet oorspronkelijk uit deze doos, wat ook de afmetingen van balansvak en balans bewijzen. Van balans inv. 3840 ontbreken de touwtjes.

De vakindeling in de drie dozen beantwoordt aan de meest voorkomende indeling, met dertien vakjes voor de gewichten. In elke doos ontbreekt het schuifdekseltje van het azenvakje en in doos inv. 3059 is het balansvakje bekleed met een bebloemd behangpapier. De doosjes bezitten geen schuiflade voor gewichten.

Het aantal gewichten in de dozen bedraagt negen (inv. 3059), elf (inv. 3840) en 12 (inv. 3841). Alle azen ontbreken. Alle gewichten

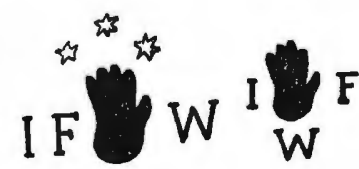

afb. 8 dragen op de keerzijde één der meestermerktekens van Jan François Wolschot telkens met het stadsmerkteken van Antwerpen (afb. 8).

Zoals reeds hoger vermeld gebeurde de aanstelling van Jan François Wolschot als stadsijker en -balansmaker op dezelfde dag als van zijn Antwerpse collega Jacobus Franciscus Neusts, nl. in 1749. Neusts was ook Controleur van de Antwerpse Munt. Hij heeft talrijke muntgewichtendozen gesigneerd, maar allen werden gedateerd 1749 , daar ze allen hetzelfde etiket dragen, gedrukt met hetzelfde cliché. Men weet dus niet tot welke datum hij zijn beroep uitgeoefend heeft.

Het Bijlokemuseum bezit twee dozen van zijn hand (inv. 2177 en 3057). De eerste doos meet $15,7 \mathrm{~cm} 1 \times 7,8 \mathrm{~cm} \mathrm{~b} \times 2,3 \mathrm{~cm} \mathrm{~h}$; de tweede : $15,4 \mathrm{~cm}$ $1 \times 8,4 \mathrm{~b} \times 2,5 \mathrm{~cm}$ h. Beide dozen wijken niet af van het Vlaamse type met dertien muntgewichten. De dozen zijn onversierd.

Op de binnenzijde van het deksel is het etiket gekleefd. De houtgravure stelt in het midden een winkeltje van een ijker voor. Twee mannen zitten aan een tafel. Eén van hen hanteert de balans. Bovenaan, de wapens

(23) Cf. doos inv. 3055 , p. 11 en afb. 6. 
van Antwerpen. Links en rechts van het tafereeltje, de twee delen van het jaartal 1749. Onderaan twee opschriften. Links : „,dese (goud) gewichten moeten gewegen / worden met twee aesen voor de remedie". Rechts : "Jacobus fransiscus Neusts gesworen icker / en balansmaecker van haere Keyserlijcke / en Conincklijcke munte van Brabandt / in de ickerije op den ouver tot Antwerpen." Op de resterende ruimte, veertien afbeeldingen van verschillende munten, ook vergezeld van hun

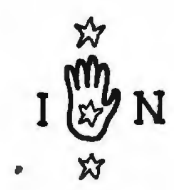

afb. 9 naam.

De balansjes vertonen op het driehoekig schaaltje het merkteken van Neusts, nl. zijn initiaal $\mathbf{N}$.

Doos inv. 2177 bevat vijftien gewichtjes ${ }^{24}$; doos inv. 3057 bevat er achttien. Alle gewichten zijn op de keerzijde gemerkt door Neusts (afb. 9). Doos inv. 2177 bevat twee koperen en twee loden azen; in doos inv. 3057 ontbreken deze gewichtjes.

\section{b) Brugge}

Van Brugge is het Bijlokemuseum slechts één doos rijk, nl. van Jan Somers II (Somer of Somere).

Jan Somers I was de zoon van Lenaert Somers, balansmaker te Brugge, die zijn beroep uitoefende vanaf 1663 tot 1687, datum van zijn afsterven. Zijn werk werd voortgezet door zijn weduwe, Catherine Hunnebelle, tot 1698. Waarschijnlijk heeft vanaf deze datum Jan Somers II het werk van zijn vader verdergezet, alhoewel zijn gewichten allen met het jaartal 1700 gedateerd zijn ${ }^{25}$.

De afmetingen van zijn doos (inv. 2174) bedragen: $14,6 \mathrm{~cm} 1 \mathrm{x}$ $7,2 \mathrm{~cm} \mathrm{~b} \times 2,5 \mathrm{~cm} \mathrm{~h}$. De doos is onversierd. Ze sluit met één sluithaak. I.p.v. een etiket op de binnenzijde van het deksel, bracht Somers er een in zwarte inkt geschreven opschrift op aan, luidend : „Dese goudt caskens met syn goudt ghe-/wichten worden ghemaect binnen / brugge

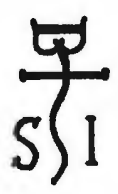

afb. 10 van Jan Somers adjusteur / du roij woonende bij de geltmunte / 1706". De namen van de corresponderende munten zijn boven de gewichtenvakjes geschreven in zwarte inkt.

Het drieboekig balansscbaltje draagt in het midden het merkteken van Somers (afb. 10) : een kromzwaard tussen de initalen $S$ en I, waarboven het stadsmerk van Brugge : de liggende $\mathrm{B}$. Het ronde schaaltje vertoont een gegraveerde versiering van een zesster in concentrische cirkels.

(24) Het gewicht van 1 pistol ontbrak in doos inv. 2177. In 1963 schonk F. Lavagne dit gewichtje aan het Bijlokemuseum. Daartoe werd het vakje even verwijd opdat dit gewicht erin zou passen.

(25) A. VISART DE BOCARME, Les ajusteurs de poids et de mesures à Bruges et leurs dénéraux, Revue belge de Numismatique, 1923, p. 49. 
In de zeven vakjes bevinden zich negen gewicbtjes (niet voltallig gezien de diepte van de vakjes), die allen op de keerzijde het merkteken van Somers dagen : een kromzwaard tussen de initialen I en $S$ en de twee delen van het jaartal 1700 , waar-

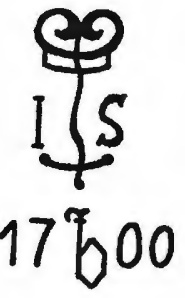

afb. 11 boven een boergondische vuurslag en waaronder de gothische $b$ van Brugge (afb. 11).

Naast deze gewichten zijn er nog vier azen bewaard gebleven. Aan een koordje bevestigd aan de doos hangt een geelkoperen pin om de gewichtjes uit hun vakjes te halen.

\section{c) Gent}

De oudste gekende balans- en gewichtenmaker vermeld in de Gentse stadsarchieven is Pieter van Oodendale ${ }^{26}$, "geboren Ceulen, maeckende balanchen gautghewichten ende andere ghelycke sorten", die op 3 augustus 1616 voor zich en zijn familie het burgerrecht betaalde. Geen enkele andere vermelding van zijn activiteit te Gent kon achterhaald worden, noch kon een muntgewichtendoos van zijn hand zijn activiteit als muntgewichten- en balansmaker in de Arteveldestad illustreren. Heeft hij dan wel zijn beroep te Gent uitgeoefend? In die tijd was het eerder zeldzaam te noemen dat een ambachtsman van beroep veranderde. Waarschijnlijk was hij verwant aan de familie van meesterbalansmakers te Keulen, genoemd Odendal ${ }^{27}$. Van deze familie zijn ons vier leden bekend die dit beroep te Keulen hebben uitgeoefend : Berndt, Ulrich, Evert en Wilhelm. Hun werkperiode ligt tussen 1640 en 1665.

Een belangrijke figuur voor Gent is ongetwijfeld Francis Martens daar het Bijlokemuseum van hem een muntgewichtendoos bezit ${ }^{28}$. Van 1652 tot 1662 (?) zou Martens zijn beroep uitgeoefend hebben ,in de Langghemunt tot Ghendt". In 1623 treffen we in Amsterdam een gewichtenijker aan met de naam Frans Martsz. ${ }^{29}$. Het merkteken van Martens te Gent met de gekroonde hoorn, zijn etiket met het Amsterdams stadswapen en de uitdrukking van de muntwaarden in guldens, laten vermoeden dat het hier één en dezelfde ijker betreft.

Zijn doos in de verzameling van het Bijlokemuseum (inv. 3056) (PL 2) $(15,4 \mathrm{~cm} 1 \times 8,7 \mathrm{~cm} \mathrm{~b} \times 3,3 \mathrm{~cm} \mathrm{~h})$, een typisch Vlaamse doos, is versierd met gegraveerde motieven.

Het etiket stelt in houtgravure een geldtellend echtpaar voor, onder bedreiging van de Dood. Hierboven de Amsterdamse stadswapens; hieronder, het opschrift: „Francis Martens woonende tot Ghendt in de Langghemunt die maeckt ende vercoopt des Gout ghewechten. Anno

(26) G. BRUNIN, L'ajusteur François de Batist, Revue belge de Numismatique, 1922, p. 120 ; Poortersboek van Gent, dl. I, p. 168.

(27) B. KISCH, op. cit., pp. 102-103; zie ook p. 6.

(28) Tentoonstellingscatalogus "Gent, 1000 Jaar Kunst en Cultuur", dl. III, Gent 1975, nr. 658 en afb. 48.

(29) Id., p. 309. 
16(6)2". Op de resterende ruimte zijn dertien verschillende munten afgebeeld, telkens met vermelding van hun naam. In de linkerbenedenhoek, het devies van Martens : „Een valsche / Schael is eenen / grouwel bij /Godt maer een oprecht gewicht is sijnen wil", gesigneerd : „Verhouen exc."

Te vermelden i.v.m. de vakindeling is dat de schuiflade onderaan in de doos verdwenen is.

Niettegenstaande het type van de balans beantwoordt aan het Vlaamse type, behoort ze oorspronkelijk niet tot deze doos vermits ze te groot is voor de beschikbare ruimte.

Van de negen gewichten zijn er acht gemerkt op de keerzijde met het merkteken van Aertus van Dunwalt ${ }^{30}$. Slechts één gewichtje vertoont het meestermerk van Francis Martens : een ge-

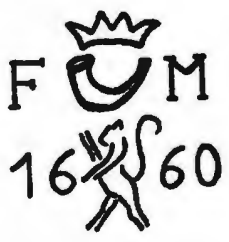

afb. 12 kroonde hoorn tussen de initialen $F$ en $M$, waaronder de klimmende Gentse leeuw tussen het jaartal 1660 (afb. 12). Volgens A. De Witte ${ }^{31}$ zou Martens ook het merkteken met de Maagd van Gent aangenomen hebben, volgens verschillende van zijn gewichten die zich 0.a. in het Muntenkabinet te Brussel bevinden. De doos bevat geen azen.

Een tastbaar bewijs van de activiteit van Franfois van de Veste (1703-1732) als gewichtenmaker te Gent, is het muntgewicht uit de collectie A. De Witte ${ }^{32}$, gedateerd 1703, gemerkt met het vlammend zwaard, de gekroonde G van Gent en de initialen F.V.D.V. In 1617 diende Barbe Ghyvoort, weduwe van Jan Somers ${ }^{33}$, een verzoekschrift in om het werk van haar echtgenoot te mogen voortzetten met de hulp van François van de Veste, van Gent, die zich ertoe verbond het beroep aan de zoon van Jan Somers aan te leren. Het verzoek werd niet ingewilligd en het was Michel de Kerchove, eveneens van Brugge, die deze opdracht mocht vervullen in 1717. Deze tekst bevestigt dus dat François van de Veste pratikeerde in die tijd en zelfs een goede faam genoot buiten Gent. In 1719 daarenboven leren de Gentse archieven ons dat François van de Veste van de stad Gent een pensioen ontving van 10 ponden. De stadsrekeningen ${ }^{34}$ stellen deze uitkering voor tot 1732, waarna geen gewag meer wordt gemaakt van deze balans- en gewichtenmaker. In het Gruuthusemuseum te Brugge wordt een koperen drukplaat bewaard om zijn etiketten te drukken die zijn dozen sierden. $\mathrm{Zij}$ stelt het klassieke thema voor van het burgerpaar dat zijn geld telt, terwijl de Dood het bedreigt. Het opschrift luidt: „Francis Van de Veste maeckt ende vercoopt dese

(30) Zie p. 12 en $\mathrm{Pl} .1 \mathrm{~b}$.

(31) A. DE WITTE, op. cit., Revue belge de Numismatique, 1895, p. 85.

(32) A. DE WIT'TE, Les dénéraux et leurs ajusteurs aux Pays-Bas méridionaux, Revue belge de Numismatique, 1899, p. 215.

(33) Zie p. 18.

(34) Stadsarchief Gent, stadsrekeningen 1718-1719, reeks 400, fo 142 en 142 vo. 
gout gewighte in de Kouborgh tot ghendt. Anno 17 " 35.

Van de Veste stond gekwalificeerd als Vrije Balansmaker wat erop wijst dat in het begin van de 18 de eeuw dit beroep te Gent eveneens vrij was ${ }^{36}$. Het zijn de misbruiken die hieruit voortvloeien die geleid hebben tot de hervormingen in 1749.

In dat jaar werd, op verzoek van hertog Karel van Lorreinen, Arnold Francis Hoofman (1749-1755) ${ }^{37}$ benoemd tot ijker van gewichten en balansen van de stad Gent. In 1755, naar het schrijven van een kandidaat voor de plaats van ijker te Gent, nl. Eugène Lambert Delmotte van Brussel" 38, was Hoofman toen "d'un grand âge et affligé d'infirmités", wat ons toelaat te veronderstellen dat het einde van zijn loopbaan naderbij was.

Verschillende dozen van deze ijker werden reeds beschreven ${ }^{39}$. Eén van hen draagt het opschrift: „Arnoldus Francis Hoofman, Gesworen balansmaecker van syne Keyserlycke en Konincklycke Maiesteyts Munte maeckt en vercoopt dese gout gewichten bij het Belfort tot Ghendt 1750".

Zijn gewichten zijn aan de keerzijde gemerkt met de Maagd van Gent gezeten in een tuin met de leeuw aan haar voeten, en de letter $G$ van $G e n t$.

Het verzoek van Eugène Lambert Delmotte (1755-1757) om benoemd te worden in de hoedanigheid van ijker van gewichten en balansen van de stad, dateert van 14 augustus $1755^{40}$. Als Brusselaar tracht hij dit verzoek te Gent te rechtvaardigen door zich de zoon en kleinzoon van ijkers te noemen, die te Brussel als balansmaker geen uitweg meer zag, vermits zijn broer Jacques zonder twijfel zijn vader Gilles zou opvolgen en er dan voor hem geen plaats meer zou zijn. Hij voegt eraan toe dat hij altijd begaan is geweest met de volmaaktheid in de kunst van het balansmaken evenals „dans la forgerie" en dat hij bijgevolg volledig geschikt zou zijn om deze functie waarvoor hij postuleert te vervullen. Hij stelt hierbij voor Hoofman te vervangen die, oud en onbekwaam, geen werk meer kon uitvoeren. Delmotte werd te Gent aanvaard, na het proefstuk voor het behalen van het meesterschap te hebben afgelegd op dezelfde dag als zijn broer Jacques te Brussel, nl. op 17 oktober 1755. Ondanks dat deze benoeming Delmotte te beurt viel, bleef Hoofman in zijn functie behouden. Volgens de Gentse stadsrekeningen van $1756^{41}$ is Eugène Lambert Delmotte in dat jaar nog actief te Gent. Hij werd toen nog ,betaelt ... over leveringhe van eene balance met alle de ganckbaerighe gewichten dienende tot eenen ligger om alsoo in cas van difficulteijt te connen gheconfronteert worden ieghens alle andere volgens ordonnantie vanden 28 meye 1756. 11113 sch. gr."

(35) A. VISART DE BOCARME, Quelques nouveaux noms d'ajusteurs brugeois, Revue belge de Numismatique, 1908, p. 264.

(36) Zie ook p. 13.

(37) G. CUMONT, Quelques poids monétaires de ma collection, Revue belge de Numismatique, 1894, pp. $379-380 ; A . D E$ WITTE, op. cit., Revue belge de Numismatique, 1895, p. 85 ; id. 1899 , p. 104.

(38) Zie verder.

(39) Muntenkabinet Brussel, verzameling Nuijttens.

(40) A. DE WITTE, op. cit., 1895, p. 49 en pp. 86-87.

(41) Stadsarchief Gent, rekeningen 1756-1757, fo $291 v^{0}$; C. GILLEMAN-A. VAN WERVEKE, Melanges, Revue belge de Numismatique, 1902, pp. 387-388. 
Het merkteken van Delmotte, aangebracht op de keerzijde van de gewichten, is de klimmende Gentse leeuw tussen de initialen $D$ en $M$ met onderaan het woord GAND ${ }^{\mathbf{4 2}}$.

Twee jaar later richtte de Gentse spoormaker Valentin (Valentijn) Place een verzoek tot de. Gentse schepenen om hem vrij te stellen van de belastingen op bier en graan, daar zijn beroep volgens hem onvoldoende kon opbrengen om er zijn gezin van te onderhouden. Het antwoord hierop was positief ${ }^{43}$. Er is echter ook een negatief antwoord bewaard gebleven, dat zinspeelt op een tweede verzoekschrift van 16 november 1758, waarin „Valentijn Place ... vrijen Balancemaecker binnen dese stadt ... onder andere voorstelt, dat syne fonctie van Balancemacker allessints nootsaecklyck ender oirboir is voor dese stadt...". Hierop volgt een voor ons interessante verantwoording van de schorsing van de vroegere toegestane vrijstelling : „Hebben d'eere UEdelen te kennen te gheven, dat ten meerderendeele vande Balancen, de gonne binne deze stad worden ghebruyckt, commen van andere plaetsen, soo van Antwerpen als elders, ende dat jeder een daervan ten vollen is voorsien, . soo dat ons duijnckt sijn versoeck van vrijdom van acht tonnen bier ende acht sacken graen geensints overeen een comt, nochte en quadereert, ten aensien vande.weijnighe utiliteijt, die de voornoemde sijne beropen fonctie, aen het publiecq saude connen toebringhen ... Ghendt, 2en Xbre 1758. (S). Mote."

Tenslotte vermelden we:nog Joannes (Baptiste) Neetesonne (1759+1793 ) en Willem (Guillaume) Volant (1793) ${ }^{44}$ als laatste gekende Gentse gewichten- en balansmakers. Neetesonne voerde als merkteken de klimmende Gentse leeuw met zijn initialen I-B-N. Willem Volant, woonachtig op het Sluizeken te Gent, werd zijn opvolger in 1793.

\section{De noordelijke Nederlanden}

De algemene kenmerken van de Noordnederlandse muntgewichtendozen sluiten nauw aan bij deze van de Vlaamse, waardoor we niet in herhalingen wensen te vervallen.

Het Bijlokemuseum bezit in haar verzameling slechts één volledige Noordnederlandse doos, en wel van Amsterdamse herkomst, één van de grote centra op gebied van het muntgewichten- en balansmaken, naast Middelburg en Rotterdam.

Een bekende Amsterdamse familie van balansmakers is de familie Linderman, van wie leden gekend zijn in de $17 \mathrm{de}$ en 18de eeuw : Jan (1744) ; Jan (1744-1758) ; Hendrik (1754-1785); Jan (1762-1805) en Wilem (1805-1838).

Hendrik Linderman werd gedoopt te Amsterdam op 14 augustus 1719 en overleed ca. 1785. Zijn zoon Jan werd eveneens aldaar geboren in 1745 en overleed vóór 1805 .

(42) A. DE WITTE, op. cit., 1899, p. 104 en pln. IV, V, IX en X.

(43) C. GILLEMAN - A. VAN WERVEKE, Deux nouveaux ajusteurs gantois, Revue belge de Numismatique, 1902, pp. 216-217.

(44) Tentoonstellingscatalogus „Gent, 1000 Jaar Kunst en Cultuur”, Gent 1975, deel III, p. 311 en nr. 674 . 
Pieter Jacob le Cointe, Amsterdamse balansmaker, werd in deze zelfde stad op 10 november 1770 aangesteld als ijkmeester-generaal der Verenigde Nederlanden. Hij overleed op 9 september 1781.

Wij hebben hier deze summiere biografische gegevens aan toegevoegd vermits het Bijlokemuseum een doos bezit van deze ambachtslui (inv. 2178).

Deze doos is $14 \mathrm{~cm}$ lang, $6,8 \mathrm{~cm}$ breed en $3,3 \mathrm{~cm}$ hoog. Ze sluit met één haak en is onversierd.

Het etiket op de binnenzijde van het deksel stelt, in een gekleurde gravure, in het midden een wisselaar voor onder de bedreiging van de Dood. Deze voorstelling, beschreven in een cartouche, is bekroond met het Amsterdams wapenschild. Op de resterende ruimte zijn 12 munten af gebeeld vergezeld van hun naam. Rechts onder, een inscriptie : „Dese Gewigte werden / Gemaakt en Verkogt by / H. LINDERMAN en zoon / op de Nieuwendyk 't Veertiende / huys van den Dam en op de Zaal / boven de Beurs tot Amsterdam."

Te vermelden is dat het rond en driehoekig schaaltje van het balansje vervaardigd zijn uit vertind geelkoper.

In de doos werd één groot vak in het midden voorzien voor de balans, 9 kleine voor de gewichten en één met schuifdeksel voor de azen rechts in de doos. Onderaan in de doos bevindt zich een schuiflade voor 10 gewichten. Bij elk vakje is de naam van de corresponderende munt in zwarte inkt bijgeschreven.

Het gewichtenaantal is volledig : 12 in de doos en 10 in de schuiflade (er bevindt zich meer dan één gewicht in elk vakje). Alle gewichten zijn op de keerzijde gemerkt met een klimmende gekroonde leeuw met zwaard en pijlenbundel waaromheen de initialen P.I.L.C. (Pieter Jacob Le Cointe) ${ }^{45}$, uitgespaard op een verdiept ovalen achtergrond. De letters L en $N$, de jaarletters van respectievelijk 1728 en 1730, bevinden zich eveneens op de keerzijde (PL $1 \mathrm{~d}$ ). Op de voorzijde, de afbeelding van de munt.

(45) K.M.C. ZEVENBOOM - D.A. WITTOP KONING, op. cit., p. 94. 